\title{
Patient safety in Neonatal Intensive Care Units: Neonatal patient safety
}

\author{
Segurança do paciente em Unidades de Terapia Intensiva Neonatal: Segurança do paciente
}

neonatal

Seguridad del paciente en Unidad de Terapia Intensiva Neonatal: Seguridad del paciente neonatal

Received: 06/10/2021 | Reviewed: 06/18/2021 | Accept: 07/07/2021 | Published: 07/23/2021

Maria Berenice Gomes Nascimento Pinheiro

ORCID: https://orcid.org/0000-0002-9095-1138

Federal University of Campina Grande, Brazil

E-mail: berenice_pinheiro@hotmail.com

Thaís Moura Gascón

ORCID: https://orcid.org/0000-0001-5557-6160 Clinical Laboratory Analysis of ABC Medical School Foundation, Brazil E-mail: tmoura46@gmail.com

Lourdes Conceição Martins

ORCID: https://orcid.org/0000-0001-9996-2725 University of São Paulo, Brazil E-mail: lourdes@usp.com.br

Fernando Luiz Affonso Fonseca

ORCID: https://orcid.org/0000-0003-1223-1589 Federal University of São Paulo, Brazil E-mail: profferfonseca@gmail.com

\begin{abstract}
Introduction: Patient Safety in a Neonatal Intensive Care Unit is to reduce as little as possible the risk of causing harmful acts in the course of care. Objective: This study aimed to search together with the scientific literature which factors compromise patient safety in the neonatal care unit. Methods: For this an integrative review was performed on the Pubmed and Scielo platforms, using a combination of the descriptors "Patient Safety" or "Patient Safety" and "Neonatology" or "Neonatology" and "Hospital" and "Infection" or "Infection". 27 articles that after the inclusion and exclusion criteria were analyzed and totaled in 7 manuscripts for the study. Results: The results showed that patient safety is compromised by factors related to multiprofessional work and the treatment received. Conclusion: Proposals include the elaboration of tools (protocols, checklists, among others) that could effectively help the establishment of a safety culture and promote the theme.
\end{abstract}

Keywords: Patient Safety; Neonatology; Hospital; Infection.

\section{Resumo}

Introdução: A segurança do paciente em uma Unidade de Terapia Intensiva Neonatal é minimizar o risco de causar atos prejudiciais no decorrer do cuidado. Objetivo: Este estudo teve como objetivo buscar junto à literatura científica quais os fatores que comprometem a segurança do paciente em unidade de assistência neonatal. Métodos: Foi realizada revisão integrativa nas plataformas Pubmed e Scielo, utilizando a combinação dos descritores "Segurança do paciente" ou "Segurança do paciente" e "Neonatologia" ou "Neonatologia" e "Hospital" e "Infecção" ou "Infecção.". 27 artigos que após os critérios de inclusão e exclusão foram analisados e 7 manuscritos foram totalizados para o estudo. Resultados: Os resultados mostraram que a segurança do paciente está comprometida por fatores relacionados ao trabalho multiprofissional e ao tratamento recebido. Conclusão: As propostas incluem o desenvolvimento de ferramentas (protocolos, checklists, entre outros) que possam efetivamente auxiliar no estabelecimento de uma cultura de segurança e na promoção do tema.

Palavras-chave: Segurança do paciente; Neonatologia; Hospital; Infecção.

\section{Resumen}

Introducción: La seguridad del paciente en una Unidad de Cuidados Intensivos Neonatales es reducir al mínimo el riesgo de provocar actos nocivos en el curso de la atención. Objetivo: Este estudio tuvo como objetivo buscar junto con la literatura científica qué factores comprometen la seguridad del paciente en la unidad de cuidados neonatales. Métodos: Se realizó una revisión integradora en las plataformas Pubmed y Scielo, utilizando una combinación de los descriptores "Seguridad del paciente" o "Seguridad del paciente" y "Neonatología" o "Neonatología" y "Hospital" y "Infección" o "Infección". 27 artículos que luego de los criterios de inclusión y exclusión fueron analizados y totalizada 7 manuscritos para el estudio. Resultados: Los resultados mostraron que la seguridad del paciente es comprometida por factores relacionados con el trabajo multiprofesional y el trato recibido. Conclusión: Las propuestas incluyen la elaboración de 
herramientas (protocolos, listas de verificación, entre otras) que puedan ayudar de manera efectiva al establecimiento de una cultura de seguridad y promover la temática.

Palabras clave: Seguridad del paciente; Neonatología; Hospital; Infección.

\section{Introduction}

Safety in health care is a topic that has been very discussed and widely disseminated due to the fact it aims to prevent unnecessary harms when providing support. In Intensive Care Units (ICUs), unsafe assistance may bring about serious issues since most of its patients are in grave health conditions and need to use a large number of equipment as well as undergo invasive procedures. When Neonatal ICU (NICU) comes in, another challenging aspect comes up: its population ranks at the top of the list of priorities regarding the decrease in child mortality, which is one of the quality-of-life indicators related to health and the level of development of a country.

In order to decrease neonatal mortality, encompassing measures must be taken in several sectors, including newborn care (NC) practices. The specific characteristics of these patients demand specific knowledge and training from healthcare practitioners, who in turn acquire technical skills, clinical experience, sensibility, competence, and a deeper sense of responsibility towards care.

The term good healthcare service is defined by the Brazilian Health Regulatory Agency (ANVISA), (Agencia Nacional de Vigilância Sanitária; 2013) as the total satisfaction of an individual when such service is provided. It is measured by a holistic approach, and it is considered satisfactory when the benefits provided by the assistance surpass the harms. Based on this concept, it can be understood that healthcare quality is a synonym of patient safety Health Organization Costa et al (2021).

Patient safety is a subject that has been the priority focus of healthcare services due not only to the global increase in harmful healthcare services that cause physical and/or psychological impairment in patients and health professionals, but also to the exorbitant expenses generated by iatrogenic errors Marinho et al. (2016).

According to the World Health Organization (WHO) patient safety is defined as the reduction of risk of unnecessary harm associated with health care to an acceptable minimum. The "acceptable minimum" refers to everything that is viable within the current knowledge, the available resources, and the context in which the assistance is provided, i.e., the risks the patient is subjected to if not treated. In other words, patient safety is the reduction of unsafe acts when assistance is provided and the use of the best practices so that the best possible results for the patient can be achieved (Health Organization: WHO, 2009).

The WHO, along with the World Alliance for Patient Safety, has been establishing guidelines and strategies to stimulate health professionals and individuals in general to promote a safe culture in healthcare services. One of the proposals is related to Global Challenges, and it aims to identify risks to patients (Negesliskii C, 2015).

According to Gomes, Salvador, Rodrigues, et al. 2015, patient safety is the reduction in risks of causing harmful acts to a minimum throughout the assistance; therefore, adverse effects (AE) can be reduced, resulting in safe health care delivered to patients. These authors also define $\mathrm{AE}$ as incidents that are likely to happen throughout the assistance which bring harm to the patient.

The presence of AE in specific scenarios like NICU is even more alarming because it is a center of reference in the treatment of severe cases. Given the phisiological instability of the patients, the simultaneous use of many equipment and instruments, as well as the constant interventions and intensive assistance, NICU is a place where mistakes are bound to happen with grave consequences to patients. Lachman et al(2014).

In these units, the design of actions that focus on safe care are of utmost importance due to the presence of complex equipment and constant administration of medications and nourishment. The National Program of Patient Safety (PNSP) was created in Brazil in 2013 with the aim of reducing AE and strengthening the patient safety culture. It is responsible for the making 
of protocols and their implementation at health institutions. (Brasil Ministério da Saúde, 2013). By including topics like safe surgery, hand sanitation, pressure injury prevention, fall prevention, safe prescription, and administration of medications as well as the correct identification of patients, these protocols have become guiding tools for risk reduction and safety improvement Demirda, et al. (2021).

However, there is not a single program specifically developed for neonatal assistance units; thus, the following questions come up: What does the scientific literature reveal regarding patient safety in neonatal care units? Which factors compromise the safety of these patients? According to what has been described, the evaluation of the literature may help not only reinforce the positive aspects but also work on the negative points found in it. Moreover, this evaluation will be of great help to stimulate and promote sensibility among health assisting professionals and to produce knowledge Kumar, et al. (2018); Benaima et al. (2020). The aim of this study is to investigate which factors compromise patient safety in neonatal care units. A deep analysis on such factors, especially in NICUs with their so debilitated patients, is of utmost importance to identify risks, establish strategies and implement effective actions in the care routine.

\section{Method}

It is an integrative review with a qualitative approach, following the six recommended steps: 1. Definition of the guiding question; 2. Search and selection of articles in the literature; 3 . Definition of the information to be extracted from the articles; 4. Evaluation of studies; 5. Interpretation of results; 6. Presentation of the review and synthesis of the knowledge obtained (Mendes et al. 2008). To guide the research, the following research questions were elaborated: What do scientific publications address about Patient Safety in Neonatal Care Units? And what factors compromise the safety of these patients?

To perform the searches, the descriptors were defined through the Virtual Health Library (VHL) website (http://decs.bvs.br), being used as descriptors: U "Patient safety" or "Patient Safety" and "Neonatology" or "Neonatology" and "Hospital" and "Infection" or "Infection" were performed. The search was carried out in the LILACS, BDENF and MEDLINE databases, and in the virtual library SCIELO.

To select the sample, the following inclusion criteria were used: articles published in Portuguese and English, from 2010 to 2019, with full text available free of charge, in the hospital context. Publications that did not relate to the theme of the study and that presented duplicity were excluded.

The data collection was carried out between June 2018 and July 2018. The selected articles were organized by date of publication, from the most recent to the oldest, and after full reading, the data were categorized according to the analysis technique thematic content (Bardin 2010)

\section{Results}

The search carried out in the Pubmed and Scielo database generated a total of 27 articles. After screening, reading titles and abstracts, 21 articles were selected for full reading. Of these, 07 papers met the inclusion criteria for this review (Flowchart 1). It's noteworthy the lack of free access to most international publications, one of the selection criteria of this research.

A summary of the articles selected through Table 1 is presented. The main results of the studies found in the table below were organized so that the type of study, year, objective and main results could be analyzed. 
Table 1 - Main results from the manuscripts.

\begin{tabular}{|c|c|c|c|c|c|}
\hline $\mathbf{N}^{0}$ & Authors & Year & Type of study & Objectives & Main results \\
\hline 01 & Crezeé KL et al & 2017 & $\begin{array}{l}\text { Cohort } \\
\text { prospective } \\
\text { study }\end{array}$ & $\begin{array}{l}\text { To establish stages } \\
\text { for extubation criteria } \\
\text { in order to reduce the } \\
\text { number of unplanned } \\
\text { extubation events. }\end{array}$ & $\begin{array}{l}\text { Results revealed } 67 \text { unplanned extubation } \\
\text { events, with } 46 \text { events in the beginning of } \\
\text { the study in } 2013 \text { and } 21 \text { events in } 2014 \\
\text { after the guidelines were implemented, } \\
\text { representing a decrease of } 64 \% \text { in the } \\
\text { total of unplanned extubation events } \\
\text { (from } 46 \text { to } 21, \text { p }<0.001 \text { ). Besides, the } \\
\text { monthly rates of unplanned extubation } \\
\text { decreased in } 50 \% \text { (from } 3.8 \text { to } 1.9 \text { ), and } \\
\text { these cases per } 100 \text { days of ventilation } \\
\text { decreased in } 53 \% \text { (from } 1.15 \text { to } 0.54 \text { ). }\end{array}$ \\
\hline 02 & Tawfik DS et al & 2017 & $\begin{array}{l}\text { Observational } \\
\text { retrospective } \\
\text { study }\end{array}$ & $\begin{array}{l}\text { To analyze the } \\
\text { prevalence of burnout } \\
\text { in neonatal ICU units in } \\
\text { California, and to } \\
\text { evaluate the relation } \\
\text { between burnout and } \\
\text { healthcare associated } \\
\text { infection (HAI) rates in } \\
\text { very low birth weight } \\
\text { newborns. }\end{array}$ & $\begin{array}{l}\text { Variable prevalence related to burnout } \\
\text { were observed in the analyzed NICUs } \\
\text { (mean of } 25.2 \pm 10.1 \% \text { ). In relation to } \\
\text { health, infection rates were } 8.3 \pm 5.1 \% \\
\text { during the period the study was carried } \\
\text { out. Higher burnout prevalence was } \\
\text { found among nurses, respiratory } \\
\text { therapists } \\
\text { physicians vs. } 17 \pm 19 \% \text { for physicians) } \\
\text { daytime workers ( } 30 \pm 3 \% \text { vs. } 25 \pm 4 \% \\
\text { for night-time workers) and those } \\
\text { professionals who had been working for } \\
5 \text { years or longer ( } 29 \pm 2 \% \text { vs. } 16 \pm 6 \% \\
\text { for those who had been working for less } \\
\text { than } 3 \text { years). } \\
\text { Overall burnout rates did not show any } \\
\text { correlation with the rates adjusted to the } \\
\text { risk of healthcare-associated infections } \\
\text { (HAI) (r=-0.133). The analysis of items } \\
\text { revealed positive association between } \\
\text { HAI and perceptions of hard work (odds } \\
\text { ratio of } 1.15,95 \% \text { confidence interval } \\
1.04-1.28 \text { ). The sensitivity analysis of } \\
\text { high-volume NICUs suggests a moderate } \\
\text { correlation between the prevalence of } \\
\text { burnout and HAI ( } \mathrm{r}=0.34 \text { ). }\end{array}$ \\
\hline 03 & $\begin{array}{l}\text { Cheong SM et } \\
\text { al }\end{array}$ & 2015 & $\begin{array}{l}\text { Documental } \\
\text { retrospective } \\
\text { study }\end{array}$ & $\begin{array}{l}\text { To evaluate the current } \\
\text { procedure regarding the } \\
\text { use of double-lumen } \\
\text { central catheter, } \\
\text { inserted in the } \\
\text { peripheral vein, and its } \\
\text { related complications } \\
\text { in very low weight } \\
\text { newborns in NICUs; to } \\
\text { identify risk factors for } \\
\text { the development of } \\
\text { bloodstream catheter- } \\
\text { related infections in } \\
\text { those babies. }\end{array}$ & $\begin{array}{l}\text { The total duration over which the } \\
\text { peripherally inserted double-lumen } \\
\text { central catheter (PIDLCC) remained in } \\
\text { place was } 1,121 \text { days (mean of } 28.5 \\
18.2 \text { days), accounting for a total number } \\
\text { of } 85 \text { catheters. The dressing at the } \\
\text { insertion site was disinfected with } \\
\text { povidone-iodine and changed twice a } \\
\text { week. Four infants ( } 10.3 \% \text {, mean age of } \\
48 \text { days) had catheter-associated } \\
\text { bloodstream infection (CA-BSI) with an } \\
\text { infection rate of } 3.57 \text { per } 1,000 \text { catheter- } \\
\text { day. The mean of days of PIDLCC } \\
\text { insertions in } 35 \text { children without CA-BSI } \\
\text { was } 26.5 \text {. The isolated organisms were } \\
\text { Staphylococcus epidermidis, } \\
\text { Staphylococcus aureus } \\
\text { Staphylococcus capitis ureolytic. The } \\
\text { study showed a significant difference } \\
\text { regarding the duration of use of delay } \\
\text { catheters (p=0.023) and intraventricular } \\
\text { hemorrhage (p=0.043) between CA-BSI } \\
\text { group and non-CA-BSI group. Five } \\
\text { infants ( } 12.8 \% \text { ) had abnormal results for }\end{array}$ \\
\hline
\end{tabular}




\begin{tabular}{|c|c|c|c|c|c|}
\hline & & & & & $\begin{array}{l}\text { thyroid function, two out of those five } \\
\text { patients were supplemented with } \\
\text { thyroxine at discharge. However, the } \\
\text { duration of use of PIDLCC and abnormal } \\
\text { thyroid function were not statistically } \\
\text { significant ( }=0.218) \text {. One infant }(2.5 \%) \\
\text { died, but its death was not related to CA- } \\
\text { BSI. No serious adverse effects } \\
\text { secondary to PIDLCC were observed. }\end{array}$ \\
\hline 04 & $\begin{array}{l}\text { Wójkowska- } \\
\text { Mach J et al }\end{array}$ & 2016 & Cohort study & $\begin{array}{l}\text { To summarize the } \\
\text { results of an ongoing } \\
\text { surveillance program, } \\
\text { which defines delayed } \\
\text { pneumonia as } \\
\text { associated or not to the } \\
\text { respiratory support at } \\
\text { the NICU and to the } \\
\text { distribution of causing } \\
\text { pathogens at the Polish } \\
\text { Neonatal Surveillance } \\
\text { Network. }\end{array}$ & $\begin{array}{l}\text { The incidence was } 3.1 / 1000 \text { patient-day. } \\
\text { The mean gestational age as well as the } \\
\text { birth weight of infants with delayed } \\
\text { pneumonia were significantly lower. The } \\
\text { incidence of pneumonia associated to } \\
\text { ventilation was } 18.2 / 1000 \text { patient-day for } \\
\text { those on mechanical ventilation (MV), } \\
\text { whereas the rates of those who were on } \\
\text { CPAP were as low as } 7.7 / 1000 \text { patient- } \\
\text { day. MV significantly increased the risk } \\
\text { of pneumonia, but MV or CPAP, when } \\
\text { used for less than } 10 \text { days, did not } \\
\text { increase the risk of delayed pneumonia. } \\
\text { The long-term use of central or peripheral } \\
\text { venous catheters and the long-term total } \\
\text { parenteral nutrition were significantly } \\
\text { associated with delayed pneumonia. The } \\
\text { isolated microorganisms in cases of } \\
\text { delayed pneumonia were gram-positive } \\
\text { cocci (53.5\%) and gram-negative rods, } \\
\text { with predominance of E. coli. } \\
\text { Nonfermentative bacilli were more } \\
\text { significantly found in MV pneumonia } \\
\text { cases than in other cases. }\end{array}$ \\
\hline 05 & $\begin{array}{l}\text { Vermeulen } \mathrm{JM} \\
\text { et al }\end{array}$ & 2014 & $\begin{array}{l}\text { Retrospective } \\
\text { and } \\
\text { prospective } \\
\text { observational } \\
\text { study }\end{array}$ & $\begin{array}{l}\text { To record the adverse } \\
\text { effects in order to } \\
\text { improve patient } \\
\text { safety in a Pediatric } \\
\text { ICU; to evaluate rates } \\
\text { and types of adverse } \\
\text { events using two } \\
\text { different record } \\
\text { methods; to describe } \\
\text { the characteristics of } \\
\text { patients who suffered } \\
\text { adverse events. }\end{array}$ & $\begin{array}{l}\text { The study identified } 260 \text { adverse } \\
\text { events in } 61 \text { patients }(50.8 / 100 \text { patient- } \\
\text { day). } 19 \text { patients }(24 \%) \text { did not suffer } \\
\text { adverse events. Catheter complications, } \\
\text { hypoglycemia and endotracheal tube } \\
\text { malpositioning were the most frequent } \\
\text { cases. Prospective registration during } 58 \\
\text { ward rounds revealed } 272 \text { adverse effects } \\
\text { in } 236 \text { patients ( } 27.2 / 100 \text { patient-day), } \\
\text { especially catheter complications, } \\
\text { nosocomial infections, and surgical } \\
\text { complications. } 132 \text { out of } 236 \text { patients } \\
\text { (56\%) did not experience adverse effects. } \\
\text { Those who suffered adverse events } \\
\text { underwent MV significantly more } \\
\text { frequently. Hospitalization period was } \\
\text { significantly associated with the number } \\
\text { of adverse events. }\end{array}$ \\
\hline 06 & $\begin{array}{l}\text { Sherenian } \mathrm{M} \text { et } \\
\text { al }\end{array}$ & 2013 & $\begin{array}{l}\text { Systematic } \\
\text { review }\end{array}$ & $\begin{array}{l}\text { To assess how the } \\
\text { nurse-patient relation } \\
\text { or nursing workload } \\
\text { affects the results in } \\
\text { NICU. }\end{array}$ & $\begin{array}{l}\text { A total of } 07 \text { studies fulfilled the inclusion } \\
\text { criteria for this review. Three of them } \\
\text { were on the same group of patients. Only } \\
04 \text { studies reported death related to nurse- } \\
\text { patient relation before NICU discharge. } \\
\text { Among these four, three studies revealed } \\
\text { an association between a lower nurse- } \\
\text { patient relation and a higher mortality } \\
\text { rate, and one of them reported the } \\
\text { opposite. As each study used a different } \\
\text { definition for nursing personnel, a meta- } \\
\text { analysis could not be performed. }\end{array}$ \\
\hline
\end{tabular}




\begin{tabular}{|c|c|c|c|c|c|}
\hline 07 & $\begin{array}{l}\text { Romanelli RCM } \\
\text { et al }\end{array}$ & 2013 & $\begin{array}{l}\text { Retrospective } \\
\text { study }\end{array}$ & $\begin{array}{l}\text { To describe the } \\
\text { occurrence of } \\
\text { healthcare-associated } \\
\text { infections (HAIs) in a } \\
\text { neonatal unit of public } \\
\text { referral hospital in Belo } \\
\text { Horizonte, Minas } \\
\text { Gerais, Brazil, based on } \\
\text { international criteria. }\end{array}$ & $\begin{array}{l}\text { A total of } 325 \text { episodes of infection in } \\
\text { newborns were notified and overall } \\
\text { incidence density of infections was } \\
22.8 / 1,000 \text { patient-day, with a rate of } \\
36.7 \% \text { of newborns. Sepsis was the main } \\
\text { infection }(62.5 \%) \text { reported. The incidence } \\
\text { density of infections was higher in } \\
\text { neonates weighing less than } 750 \mathrm{~g} \\
(42.4 / 1000 \text { patient-day). There were } \\
18.15 \text { episodes of central venous catheter } \\
\text { related sepsis/1000 central venous } \\
\text { catheter-day and } 19.29 \text { umbilical catheter } \\
\text { related sepsis } / 1000 \text { umbilical catheter- } \\
\text { day. Microorganisms were isolated in } 122 \\
\text { (37.5\%) cases of reported infections, } \\
\text { mainly defined as Staphylococcus, } \\
\text { coagulase negative, and Staphylococcus } \\
\text { aureus (51 cases). Mortality and lethality } \\
\text { rates were } 4.3 \% \text { and } 17,12 \% \text {, } \\
\text { respectively. }\end{array}$ \\
\hline
\end{tabular}

Source: Authors.

\section{Factors that compromise patient safety in the intensive care unit}

It was possible to identify the factors that compromise patient safety according to the selected articles. For a better understanding, these factors were categorized as follows: Factors that compromise patient safety in the intensive care unit related to the professional; Factors that compromise patient safety in the intensive care unit related to the treatment received, as shown in Table 2.

Table 2 - Main Adverse Events described by the scientific literature.

\begin{tabular}{ll}
\hline \multicolumn{1}{c}{ Types of factors that compromise patient safety } & \multicolumn{1}{c}{ Description in the literature } \\
\hline $\begin{array}{l}\text { Factors that compromise patient safety in the intensive care unit } \\
\text { related to the professional; }\end{array}$ & $\begin{array}{l}\text { Work overload, high patient-nurse ratio, } \\
\text { Burnout Syndrome }\end{array}$ \\
\hline $\begin{array}{l}\text { Factors that compromise patient safety in the intensive care unit } \\
\text { related to the treatment received }\end{array}$ & $\begin{array}{l}\text { Invasive procedures; Antibiotic therapy; } \\
\text { Exchange of catheters, probes and drains; } \\
\text { Mechanical ventilation and orotracheal } \\
\text { intubation }\end{array}$ \\
\hline
\end{tabular}

Source: Authors.

\section{Discussion}

When identifying in the articles studied the factors that compromise patient safety, we link the discussion according to the categorization, dividing into factors related to the professional and factors related to the treatment received.

\section{Factors that compromise patient safety in the professional-related intensive care unit.}

It is known that the critically ill patient often requires fast, complex, and accurate care. When addressing patient safety and the work overload of professionals, we found a study by Serenian et al. (2013) that studies how the nurse-patient relationship or nursing workload affects the results in the NICU.

The higher proportions from patient to nurse and nursing workload are associated with increased mortality in the adult ICU. In the case of NICUs, the impact of staff on results was unknown. In this context, the authors searched the scientific literature for studies on this issue. 
Of the seven articles included in the research, only four studies reported death before discharge from the NICU in relation to the nurse-patient indexes. Three reported an association between a lower nurse-patient ratio and higher mortality, and one reported the exact opposite. As each study used a different definition of nursing personnel, a meta-analysis could not be performed.

It is important to highlight that the nurse-patient proportions seem to affect the outcomes of neonatal intensive care, but the limitations of the existing literature prevent clear conclusions about optimal staffing strategies. Evidence-based standards for staff could impact public policy and lead to improvements in patient safety and decreased rates of adverse outcomes.

The nursing professional brings a range of responsibility about the execution and provision of care assistance to patients. Regarding assistance in the NICU, its responsibility is doubled if we take into account that in this hospital environment there is a patient at imminent risk of death, as well as complications such as infections. And with technological advances and constant technical and scientific development, there was a change in the profile of hospitalized children, demanding from nursing professionals in the neonatal and pediatric areas, more complex care and invasive procedures to guarantee the survival of this clientele.

According to studies carried out by Cheong et al. (2016), this complexity of procedures results in a greater propensity for errors along with increased vulnerability. Underweight children are more vulnerable to errors and adverse events ten times more in the NICU. In this study, it points out the high infection rates related to the poor performance of teamwork, increasing the concern with Burnout as a factor that compromises Patient Safety.

Analyzing the study carried out Tawfik et al. (2017), the authors launch a discussion about the relationship between infection rates associated with poor performance in other areas of the safety culture including teamwork and safety climate, increasing the burnout concern as source of decreased quality of health care, particularly for critically ill pediatric patients. In that study, forty-four NICUs participated in this study, 2073 out of 3294 surveys returned a response rate of $62.9 \%$. The main finding of this study is that the burnout of the neonatal provider the prevalence is highest among non-doctors, day workers and more experienced workers.

In addition, perceptions of working hard are associated with an increase in Healthcare-Related Infections. Non-doctor reported higher average burnout scores, a cohort composed mainly of nurses in this study, this is consistent with lower perceptions of other components of the safety culture observed among nurses, including the safety climate, teamwork and management perceptions.

The definition of Burnout most commonly found in the literature on the subject comprises this phenomenon as a psychological syndrome, which arises from the chronic emotional tension demonstrated by those professionals working in functions that require direct and excessive contact with people in need of care Schaufeli et al. (2017).

And making a general survey of the activities of this professional stands out obtaining the patient's history, carrying out physical exams, executing treatment, advising and teaching health maintenance and guiding the family towards a continuity of treatment and measures. In this unit you need to have scientific and practical knowledge so that you can make quick and concrete decisions, transmitted to the whole team and mainly reducing the risks that threaten Patient Safety. Thus, the presence of Burnout is seen as a factor that compromises Patient Safety.

Another interesting finding is that Burnout syndrome was more present in workers who work during the daytaw. Analyzing this fact, it's observed that, although night work can be challenging in its interruption of daily rhythm and difficulty in coordinating responsibilities outside of work, it is possible that the work of the day shift is more demanding for many, due to diagnoses, more numerous treatment activities and conversations with families that take place during the day Tawfik_D.S et al.(2017). 
In the study it also points out that the increase in burnout in units with an insufficient number of professionals increases the infection rates when the nurses feel overwhelmed, there is probably a lack of attention to details necessary to prevent infections. Therefore, for these researchers they propose that managers increase their sensitivity to episodes of personal shortages, with the use of "time outs" and daily meetings to increase awareness, encourage adherence to the protocol and support from peers, and increase general surveillance.

Given the above, it is believed that overworked professionals may be less likely to follow institutional protocols, they may be less likely to notice errors or omissions in the provision of health care.

\section{Factors that compromise patient safety in the intensive care unit related to the treatment received.}

In recent years, technical advances and improved assistance in terms of neonatal intensive care (NICU) have led to an increase in the survival of premature infants and also of very low birth weight newborns (weight below 1,500g). This improvement is often the result of greater use of invasive procedures (central venous catheterization, parenteral nutrition, invasive mechanical ventilation) and the use of broad-spectrum antibiotic therapy, associated with longer hospital stays and provision of services by multiple caregivers. Such factors, combined with the immaturity of the immune, gastrointestinal and skin barrier functions, contribute to Adverse Events.

In neonatology, advances in intensive care, the availability of invasive devices such as central venous catheter (CVC) and devices for MV and formulas for total parenteral nutrition, among others, provided indisputable improvements, mainly expressed by the increase in the survival of newborns. - premature and low birth weight. Paradoxically, the use of these advances, are also identified as risk factors for Adverse Events in neonatal units.

In the systematic review we were able to study the Adverse Events associated with some of these procedures. In the study by Crezeé et al. (2017), the authors approach unplanned extubating among newborns as a proposal for the safety of intubated patients. This study points out the need for at least 2 caregivers at the bedside to move an intubated subject; standardization of the position of the head and endotracheal tube (ETT); define a defined methodology for ETT security; introduce a post-operative handoff to improve communication; and implement a post-extubating assessment tool. This study arises from the need to observe and implement actions that increase longer intubation, less involvement of the trachea in neonates and less routine use of sedation.

The presence of Adverse Events in relation to extubating can cause rapid cardiorespiratory deterioration and other adverse effects, such as airway trauma, subglottic stenosis induced by repetitive intubations and pneumonia associated with ventilations.

In the routine of care for the Newborn in an ICU, we know that he goes through several routine procedures, which include daily weighing, treatment activities and diagnostics, among other actions that endanger the safety of the intubated patient. In this study, it proposes as a suggestion for Patient Safety potentially better practices with an initiative to improve the quality of care for the newborn, comparing accidental extubation rates (January 2013 to December 2013) and later (January 2014 to December 2014) after the implementation of the prevention guidelines.

An important action included educating the team on the frequency and significance of unplanned extubations, making tube safety a high priority. Adopting alert measures at the bedside, informing intubated and mechanically ventilated children, made professionals take more care in handling.

The fixation of the endotracheal tube and the sedation of active and agitated children are also pointed out as factors that compromise the safety of this patient. A tube without a correct fixation favors extubating, especially during suction, weighing, and repositioning of the infant. In light of this, the study emphasizes improving constant surveillance and changing culture within the NICU so that all team members recognize unplanned extubating as a preventable event. 
Another treatment that has been found in studies that can be challenging for patient safety in the NICU is the use of Mechanical Ventilation. In the study by Wójkowska-Mach J et al. (2016), the authors research an ongoing surveillance program defining late pneumonia as associated or not associated with respiratory support in the NICU and the distribution of pathogens that cause the Polish Neonatological Surveillance Network (PNSN). And it was observed in the research that mechanical ventilation increased the incidence of pneumonia, while newborns who used CPAP the incidence was less.

The studies Romanelli et al. (2013), the authors carried out an active search in medical records of infections in the Neonatal Unit of Progressive Care (UNCP) of Hospital das Clínicas, Federal University of Minas Gerais (HC / UFMG) and during the study period were 886 newborns admitted to UNCP were included in this period for surveillance of infections, totaling 14,256 patient-days. 325 episodes of infection in the newborns of UNCP were reported by active search, $110(33.8 \%)$ of which were early infections and 215 (66.2\%) of late infections. Of the total, $222(25.1 \%)$ newborns had at least one episode of infection, corresponding to a proportional incidence of $36.7 \%$.

The findings of this study show the incidence density of infection by invasive device, 18.15 episodes of sepsis per 1,000 Central Venous Catheter-day (CVC-day) were observed; 5.7 episodes of pneumonia per 1,000 Mechanical Ventilations-day (MV-day) and 3.3 Urinary Tract Infections per 1,000 Bladder-Day Probes (SVD-day). The main infection associated with an invasive device was sepsis associated with CVC and higher densities were observed in the weight ranges below 1,000g, reaching 29.1 per 1000 CVC-days in patients weighing less than $750 \mathrm{~g}$ (Table 2). When only the umbilical catheter was considered, an incidence density of 19.29 per 1,000 catheter-days was obtained.

Corroborating this study, another study by Vermeulen et al. (2014) carried out a retrospective audit on adverse events in a Children's Hospital and identified 260 adverse events in 61 patients (50.8 per 100 patient-days). Nineteen patients (24\%) had no adverse events. The study points out that factors that influence patient safety, complications of the catheter, hypoglycemia, and malposition of the endotracheal tube, requiring repositioning, were the most frequent adverse events found.

The same study did a prospective study and observed that during 58 visits to wards and revealed 272 adverse events in 236 patients (27.2 per 100 patient-days), particularly catheter complications, nosocomial infection and surgical complications. One hundred and thirty-two patients out of a total of 236 patients (56\%) did not experience an adverse event. Patients who experienced adverse events underwent mechanical ventilation significantly more frequently. The length of hospital stay was significantly associated with the number of adverse events.

The importance of optimizing measures of good clinical practices and hygiene in the preparation of medicines and foods, in the handling and administration of these must be emphasized to ensure Patient Safety.

\section{Final Considerations}

Based on the thorough analysis of the articles selected from the scientific literature, the current study aimed to investigate which factors compromise safety in healthcare in NICUs. Moreover, this study is also intended to elucidate divergent characteristics and conformations so that patient safety in ICU can be improved.

In a scenario where there is a fine line between an effective assistance and extreme care resources, reinforced by the critical unstable condition of the patients and professional burnout, NICU becomes an environment susceptible to human errors that may generate often irreversible iatrogenic $\mathrm{AE}$ when assistance is rendered.

After a deep analysis on the theme, the current study could verify which factors that compromise patient safety in ICUs are more frequently mentioned and correlated in the scientific literature.

Factors related to multiprofessional teamwork, treatment and healthcare assistance were found. Regarding professionals, burnout caused by overwork was mentioned as a compromising factor. As to treatment and healthcare assistance, the many invasive procedures performed in these units come up. 
In this context, it is possible to perceive the incorporation of new technologies in neonatal care. However, a criticalreflexive evaluation on the use of this technology and its implications is required from the ethical point of view, analyzing not only the benefits, harms, limitations, and adaptations to the needs of the newborn, but also the way this technology is used by health professionals.

The lack of articles that deeply discuss the theme was one of the limitations found in this study. Undoubtedly, the number of changes that have been occurring in this scenario is noteworthy, but discussions on the theme within all healthcare sectors should be stimulated and knowledge should be disseminated, beginning with undergraduate students, Vermeulen et al. (2014) moving on to healthcare services through permanent education actions, for example.

Further proposals include the elaboration of tools (protocols, checklists, among others) that could effectively help the establishment of a safety culture and promote the theme. It is understood that the dissemination of information from studies and protocols in professional training with efficient results in the safety care of newborns applied to the clinic reinforces the prevention of risks and adverse events to the neonatos health.

\section{Sources of funding}

This study has no financial support.

The current study did not count on any funding type. The study was supported by the publications available in databases and thank the scientific community for the productions and availability of access to the periodicals. The authors declare no conflict of interest whatsoever.

The authors declare not conflict of interesting, whether financial or relationship, that influences the writing and / or interpretation of the findings.

\section{References}

Agência Nacional de Vigilância Sanitária, 2013. Segurança do Paciente e Qualidade em Serviços de Saúde. Assistência Segura: Uma reflexão teórica aplicada à prática.

Bardin L. Análise de Conteúdo. (4th ed.).

Benaima, Upadhyayb, Talatib (2020). Journal of Global Antimicrobial. Resistance, 21, 124-129. https://doi.org/10.1016/j.jgar.2020.03.015

Brasil Ministério da Saúde. (2013). Resolução $n^{o} 36$ de 25 de julho de 2013. Brasília.

Cheong, Nakanishi, Uchiyama\& Kusuda, 2016. Outcomes of peripherally. Journal of Neonatal-Perinatal Medicine. 9, 99-105.

Costa, F., Bezerra, C., Costa, F., \& Randall (2021). Comparative assessment of off-label and unlicensed drug prescription in neonatal intensive care: FDA versus Brazilian guidelines. Anales de Pediatría, 94, 153-160.

Crezee, D. G., \& Rigby, C. (2017). Reducing Unplanned Extubations in the NICU Following Implementation of a Standardized Approach. Respiratory Care. $62,1030-1035$.

Demirda, K. \&Tezer (2021). Pediatrics and Neonatology 62 (2021). https://doi.org/10.1016/j.pedneo.2021.01.001

Gomes, S., Rodrigues, S., \& Ferreira, S (2015). A segurança do paciente nos caminhos percorridos pela enfermagem brasileira. Revista. Brasileira de Enfermagem.70, 146-154.

Health Organization (WHO), 2009. The Conceptual Framework for the International Classification for Patient Safety. https://www.who.int/patientsafety/taxonomy/icps_full_report.pdf

Kumar, S, Aryaa, D., \& Chellani (2018). Journal of Infection and Public Health 11,275-279.

Lachman, J. \& Rahi (2014). The case for quality improvement in the Neonatal Intensive Care Unit. 90, 719-723.

Marinho, R., Tourinho, R., \& M. (2016). Intervenções educativas e seu impacto na cultura de segurança: uma revisão integrativa. Enfermagem em Foco. 7, $72-$ 77.

Mendes, S., \& Galvão (2008). Revisão integrativa: método de pesquisa para a incorporação de evidências na saúde e na enfermagem. Texto Context Enferm [Internet].17(4):758-764. http://www.scielo.br/pdf/tce/v17n4/18.pdf. 
Research, Society and Development, v. 10, n. 9, e32410917044, 2021

(CC BY 4.0) | ISSN 2525-3409 | DOI: http://dx.doi.org/10.33448/rsd-v10i9.17044

Negesliskii, 2015. Efeito de uma intervenção educativa com profissionais de enfermagem acerca da segurança do paciente na administração de medicamentos injetáveis. (Tese de Doutoramento)

Romanelli, A, Mourão, C, Loyola, J, \& Clemente (2013). Infecções relacionadas à assistência a saúde baseada em critérios internacionais, realizada em unidade neonatal de cuidados progressivos de referência de Belo Horizonte, MG. Revista Brasileira de Epidemiologia. 16, 77-86.

Schaufeli, M. \& M. (2017). Professional Burnout. Routledge; doi:10.4324/9781315227979

Tawfik, S., Kan, S., Nisbet, R Lee, (2017). Burnout in the neonatal intensive care unit and its relation to healthcare-associated infections. Journal of Perinatology. 37, 315-320.

Vermeulen, Y., Van Der S., Wösten-Van A. \& Argent, (2014). Patient safety in South Africa: PICU adverse event registration. Pediatric Critical Care Medicine. 15, 464-470.. https://doi.org/10.1016/j.jgar.2020.03.015

Wójkowska, M., Borszewska, D., Gulczyńska, ,H., \& Adamski, (2016). Device-associated pneumonia of very low birth weight infants in Polish Neonatal Intensive Care Units. Advances in Medical Sciences. 61, 90-95. 